\title{
Entrepreneurial Training Curriculum Assessment: The case of New Venture Creation Learnerships
}

Marius Pretorius and Thomasz Wlodarczyk

Department of Business Management, University of Pretoria

\begin{abstract}
This paper joins the debate about how best to assess entrepreneurial training interventions, using a case-study. Contextual secondary literature about the structure and content of such interventions is briefly reviewed. Based on this review, a framework is developed and applied to the Provincial Skills Development Pilot Project's current New Venture Creation Learnership programme. This in-depth case study uses an evaluation instrument based on the entrepreneurial assessment model proposed by Pretorius (2001: 264). Results show that the chosen programme exhibits certain limitations, which restricts its success in developing entrepreneurs in line with the National Skills Development Strategy. However, the programme possesses many strengths and its limitations are easily remedied. The proposed assessment method successfully identifies the strengths and weaknesses of the programme.
\end{abstract}

JEL L26, M53

\section{Introduction}

In 2004 South Africa's total entrepreneurial activity (TEA) rate was estimated at 5.4 per cent, against a total average of 9.4 per cent amongst all countries participating in the Global Entrepreneurship Monitor (GEM) programme (Orford, Herrington \& Wood, 2004:3). Considering that the average TEA rate for developing countries is 21 per cent, South Africa is one of the least "entrepreneurially active" nations among its peers. In recognition of this, the South African government has instituted the National Skills Development Strategy (NSDS) to improve the labour force's level of skills through training interventions and learnership programmes. This strategy has raised expectations as to the development of individuals capable of creating sustainable entrepreneurial ventures. Among the guiding principles of the NSDS (Department of Labour, 2005: 2) are supporting employment creation and poverty reduction. Increasing employment is in line with the government's strategy to develop small business, which has highlighted the small business sector as an important force to generate such employment and more equitable income distribution, and to stimulate economic development (Republic of South Africa, 1995: 2). Consequently, the NSDS has developed ambitious expectations of the New Venture Creation Learnership (NVCL) programme in assisting to close this gap.

This study is aims to aid developing countries that are seeking guidelines and answers as they increasingly turn toward entrepreneurship as a viable vehicle for promoting economic development (Hood \& Young, 1993: 1). Current government intervention efforts to develop entrepreneurship do not seem to be making much headway. According to Davies (2002: 7), the "government is on record for admitting that, despite the huge investment in support structures and training, there is little appreciable positive impact evident in the SMME sector." Consequently, the National 
Skills Development Strategy is concerned with the development of new ventures, with a target of 7000 new ventures created by 2010. Within this context, the NSD strategy specifically focuses on the pre-founding (incubation) and infancy stages of the life cycle of entrepreneurial ventures.

As an alternative to standard education, learnership is a learning programme that leads to an occupational qualification. A typical learnership consists of:

- an institutional learning component amounting to approximately 30 per cent of the total learning time and

- a workplace-learning component where the learner is placed with an employer for the remainder of the learning period.

The entrepreneurship development approach of the NVC programme is built on the principles of outcomes-based education (OBE). As Pooe (2002: 4) explains, OBE is not about what the tuition system provides and teachers teach, but about what students actually learn and what they are able to do at the end of a learning experience. Since the aim of the NVC intervention is the tangible establishment of new ventures, the very concept of entrepreneurship education and training in itself is inherently outcomes-based. The learnership process imparts knowledge through formal teaching and develops tangible skills through experiential learning activities, which include behavioural and emotional components that are difficult to incorporate within a traditional classroom setting (Pooe, 2002: 11). Theoretical knowledge is important for developing skills in systematic innovation, risk reduction and management (Amos \& Maas, 2001: 7), and enables students to anticipate the future instead of relying on luck or intuition (Alberti, Sciascia \& Poli, 2004: 13). Timmons (1994) states that inclusion of training materials should:

- convince the student to become actively involved in entrepreneurship;

- facilitate an understanding of the dynamic nature of the world of entrepreneurship; and

- slow down the reality shock of the real world by means of formal or informal tuition.
It follows that, in order to facilitate meaningful experiential learning, the relevant theoretical knowledge base must first be imparted to the learner, and that the content of the formal teaching must be appropriately developed in accordance with the envisaged learning outcomes. Thereafter, the approach of training delivery is important in motivating the prospective entrepreneur to pursue this field, and simulating the experiences he or she is likely to encounter in the real world.

This paper briefly explains the NVCL programme and its context, and reviews the key literature on entrepreneurship training principles. It focuses on the question of how to assess entrepreneurial training interventions, and evaluates the NVCL based on the literature, reports the assessment results following the application of the entrepreneurial education assessment tool, and finally provides conclusions.

2

\section{Research questions}

The content and level of entrepreneurship courses vary significantly depending on the objectives of the training (Pretorius 2000: 5). The key considerations that guide the choice of learnership instructional content therefore centre around matching the tuition with the expectations of the NSDS and the structure of the learnership process, the actual needs of the learners, the realities of running a business in the South African environment and fundamental entrepreneurship and business theory concepts. Therefore, the key research questions for this study of the teaching curriculum of the NVC qualification are:

- What is the context of the NSDS initiative, and what are the resulting expectations of the NVC learnership?

- Is the tuition curriculum "appropriate" in light of the expected outcomes and targets of the NSDS?

- Does the tuition content of the NVC learnership process follow recommended best practice standards as supported by academic research? 
- Does the learnership programme balance theoretical fundamentals with the dynamic nature of entrepreneurship and the realities of running a business in South Africa?

- Does the learnership programme meet the specific needs of the learners, and inspire students to become actively involved in entrepreneurship?

These questions are explored in this paper. The answers should contribute to an improved understanding of this significant government intervention, and may guide developers of entrepreneurship training programmes.

\section{3}

Why learnerships?

According to the Department of Labour (2005: 15), the formal sector is not creating enough jobs for all the young people entering the labour market annually, and the potential exists for some young people to become entrepreneurs if assisted to do so. As illustrated by the NSDS targets for new venture creation, the government has high expectations for the performance of the NVC learnership in offering this assistance. Of course, the creation of a sustainable new venture depends on various factors, not least of which is the entrepreneur him or herself. Wickham (2004: 134) defines the entrepreneur as the individual who lies at the heart of the entrepreneurial process, the person who drives the whole process forward.

What really matters as an outcome in any entrepreneurial training programme is a change in behaviour to engage in the start-up process. This is known as the "start-up edge" required for venture start-up success (Pretorius \& Maartens, 2001: 13). In the case of young individuals, such as those targeted by the NSDS, this challenge is exceptionally demanding. Le Roux (2004: 12) outlines the NVC learnership model, which aims to provide a holistic intervention for fostering and enabling new business start-ups. The salient elements of the NVC model are:

- A selection process aimed at identifying individuals who possess an inherent entrepreneurial awareness;
- An institutional learning component leading to the development and submission of a business plan; and

- A practical business development phase, which includes the facilitation of access to markets and sources of finance.

The NVC learnership training aims fundamentally to provoke behavioural change in learners (Davies, 2002: 16). This model's philosophy is that learning must include knowledge transfer, as it combines components of education and training in order to facilitate the attainment of knowledge, comprehension, skill and mastery of execution through experiences that lead to relatively permanent changes in behaviour (Pretorius, 2000: 3). Pretorius (2000: 4) hypothesises that if a training process is "improved to be more applicable and practical by becoming a learning-process, more entrepreneurs will enter, succeed and contribute to the economic growth so desperately needed." The highest level of learning a learner can achieve is thus to start his or her own venture, while the least effective form of learning, in terms of bringing about behavioural change, is probably listening to a lecture. This holistic approach is required to assist persons who have embarked on entrepreneurial activities in nurturing their enterprise, and to support them with the skills and knowledge needed to run a business in a formal manner (Le Roux, 2004: 2).

This study focuses on the tuition component, which consists of content material and the facilitation of the training curriculum. The learnership training unit standards have been reviewed and updated since the publication of the initial NVC qualification in 2002, and it is now generally accepted that course content alone cannot create sustainable business ventures, nor can training in isolation "rectify a critical situation" (Van Vuuren \& Antonites, 2001: 1). Davies (2002: 5) highlights the fact that acquiring skills specific to small, medium and micro enterprises (SMMEs) is seldom achieved through structured learning, but rather through the processes of skills formation. Therefore, the design and establishment of the NVC learnership must aim to: 
- Develop appropriate skills and knowledge required for enterprise development (startups);

- Support job creation rather than qualifications as a priority; and

- Address the economic, administrative and social barriers that contribute to failures in starting and developing the enterprise.

It follows that the training curriculum should embody the same philosophy of purpose and outcomes as that which supports the learnership approach as a whole. Therefore, the development of instructional content should be geared towards tangible creation of new ventures. However, though this experiential approach is the fundamental tenet of the learnership programme, certain knowledge and theory, as Amos and Maas (2001: 7) acknowledge, is required by individuals to be successful as entrepreneurs. According to Alberti et al. (2004: 13), entrepreneurship theory is a set of empirical generalisations about how entrepreneurs should behave that allows for predictions of true outcomes. Theory must be taught to aspiring entrepreneurs because nothing is more practical than understanding the consequences of committing resources to launch a venture. Drucker (2001: 26) also highlights the need for theory, pointing out that "entrepreneurship is risky mainly because so few of the so-called entrepreneurs know what they are doing. They lack the methodology. They violate elementary and well-known rules."

\section{4}

\section{Research objectives and propositions}

The key objectives of this study are thus to find a methodology for assessing entrepreneurial interventions and apply it. An overview of the academic literature is used to develop a guideline for evaluating the training curriculum that has been compiled to support the NVC learnership. Since the outcomes of the training should be geared towards the NSDS targets, the specific context of the NSDS must first be understood. Topics for inclusion in the course content should be selected to meet the specific training needs of potential entrepreneurs at various stages of the person's entrepreneurial development (Watson \& Boshoff, 1995: 18). Consequently, a high-level profile of the typical learnership delegate must be proposed, and the particular entrepreneurial venture stage/s covered by the learnership defined. The study therefore has the following objectives:

- To explain the context of the NSDS and NVC learnership objectives: this includes a definition of the SMME life-cycle stage/s pertinent for development, and a profile of the typical learnership delegate;

- To develop, based on a review of relevant academic literature sources, an understanding of the recommended best practice standards for entrepreneurship content and training approach that should be included in a training programme: this will serve as the basis for determining whether the NVC learnership curriculum is appropriate within the context of the NSDS;

- To evaluate the NVC learnership case in depth against the standards defined within academic research literature; and

- To investigate whether the NVC learnership process has the potential to inspire new entrants into entrepreneurship, while exposing them to the dynamic nature of entrepreneurship and the realities of running a business in South Africa.

The qualification outline for the National Certificate in NVC cites various international academic references in support of its conceptual framework (South African Qualifications Authority, 2002: 4). Among these references, Van Vuuren and Antonites (2001: 1) highlight the inconsistency in viewpoints regarding the content of entrepreneurship training programmes within local and international secondary data. This is a major constraint to the development of specific guidelines for entrepreneurship training content and delivery. Consequently, this study uses the entrepreneurial performance education model proposed by Pretorius, Nieman and Van Vuuren (2005: 420) as the basis for curriculum research and evaluation. This model gives broad coverage of the factors effecting entrepreneurship education (i.e. business skills, entrepreneurial 
skills, achievement motivation, entrepreneurial success factors, approaches to business learning, application of the business plan, facilitator skill, and the overall context of the intervention), and so provides a practical focal point for discussing curriculum content and delivery. The paper therefore focuses on the following propositions:

P1: The curriculum structure of the NVC learnership resembles recommended guidelines within academic literature, as evaluated in accordance with the entrepreneurial performance education model

If this is true, then

P2: The training delivery of the NVC learnership is appropriate for the development of entrepreneurs as required by the NSDS strategy.

\section{5}

\section{Methodology}

The research design is a formal, ex post facto case study using secondary data on entrepreneurial education and then assessing the NVCL as an example case. Data was gathered using in-depth interviews with key role players (i.e. the project manager, the learnership coordinator and facilitators), and an analysis of the materials, content, delivery process and facilitation of the course. The aim was never to statistically prove differences but rather to execute a meaningful assessment of the programme. The investigation covers both the assessment tool and the programme under investigation.

To ensure contextual specificity, the literature study was based primarily on the South African context, with articles obtained from academic journals, conference proceedings and government sources such as the South African Qualification Authority (SAQA), the Department of Trade and Industry (DTI) and Department of Labour. International reference sources were included to establish a basis of support for the model, and to make the study more broadly applicable.

Firstly, government secondary data sources were consulted to build an overview of the context of the NSDS and NVC learnership initiatives. Then a review of the academic literature was undertaken to decide on the main themes that could be used as a point of departure for developing guidelines for assessing the NVC learnership. The status of available information and the level of academic consensus regarding the curriculum requirements for entrepreneurship courses were evaluated. Based on this analysis, and the relative lack of agreement among scholars about the content and structure of entrepreneurship, as mentioned above, the entrepreneurial performance education model proposed by Pretorius et al. (2005: 420) was selected as the base framework for programme evaluation. This model was found to contain many constructs relevant to entrepreneurship education, as will be outlined in the literature review in section 6 of this paper.

The literature findings were synthesised into a contextual guideline for a qualitative assessment of the content and delivery of the training curriculum supporting the NVC learnership. The evaluation consisted of two parts, namely a course content analysis and an examination of the training delivery.

- The course content was evaluated according to the multiplicative model proposed by Van Vuuren and Antonites (2001: 2):

$\mathrm{EP}=\mathrm{M}[(\mathrm{ES} \times \mathrm{BS})]$

where EP is entrepreneurial performance, $\mathrm{M}$ is motivation, $\mathrm{ES}$ is entrepreneurial skills and BS is business skills. This model is an integral part of the overall entrepreneurial performance education model selected for our evaluation. The NVC qualification outcomes and assessment criteria for each of the core unit standards were evaluated against these content guidelines.

- The training delivery and overall perceptions of the programme were evaluated by gathering qualitative feedback from NVCL practitioners by means of a questionnaire founded on the entrepreneurial training model proposed by Pretorius (2001: 264). This specific assessment tool was chosen because it is an integral part of the overall entrepreneurial performance 
education model and so was already predeveloped according to the constructs of the model. Also, the assessment tool has been successfully applied in the evaluation of other entrepreneurship programmes (Pretorius, 2001: 202; Pretorius \& Maartens, 2001: 10).

This evaluation process was an opportunity for the practical application of the entrepreneurial performance education model within a real training scenario.

The questionnaire includes of a series of questions grouped according to the constructs outlined in Pretorius' model, and feedback is collected via a seven-point scale. Participants are asked to evaluate the extent to which they agree with each of the statements in the questionnaire about the programme under evaluation. The seven-point scale assists in outlining any positive or negative deviations from the median. Anything above or below the median value of four highlights strengths and weaknesses, respectively, in the programme, as perceived by the respondents. Significant strengths and weaknesses were noted and discussed.

\section{6}

\section{Literature review}

\subsection{Academic consensus about training standards}

A suitable training curriculum for the NVC learnership is not easy to specify. At present there is no consensus among scholars of the field of entrepreneurship as to the basic content of such training interventions that aim to improve entrepreneurial performance (Van Vuuren \& Antonites, 2001: 2), and the training of entrepreneurs in South Africa is still in a very early developmental phase. In their review of entrepreneurship education and training programmes, Garavan and O'Cinneide (1994:3) found that there is a lack of accepted paradigms or theories of entrepreneurship education and training. Alberti et al. (2004: 12) mention that too many different courses show a chaotic and "undisciplined discipline", but believe that this divergence will decrease as soon as the field reaches its maturity.
Van Vuuren and Antonites (2001: 11) assess the academic consensus on the importance of various competencies implied within their multiplicative model, mentioned in section 5 . Their findings support the general view already stated, that consensus amongst academics as to the appropriate content for entrepreneurship courses is lacking. Certain competencies however, are mentioned more consistently in the literature, namely: performance motivation, creativity and innovation, opportunity identification, business plans, financial skills, marketing skills and general management skills (including organising, planning, control, coordination, strategic process, decision making and basic business management principles). In a ten-year literature review, Gorman, Hanlon and King (1997: 14) echo these points. They also stress the problems associated with the variety of approaches and directions taken by academics in this field, but similarly outline a number of consistent themes, such as the need to distinguish between entrepreneurship, enterprise and small business management education and to differentiate each of these from traditional approaches to management education. Furthermore, they report consensus on the components of an ideal structure, namely: "a focus on attributes and skills as well as tasks, an element of concrete experience derived from active participation through projects and the like, and content directed to stage of venture development and emphasising functional integration".

Most importantly, perhaps, the literature review revealed that there is significant consensus that entrepreneurship can be taught, and that entrepreneurship courses can enhance a student's propensity towards business endeavours and effect their decisions accordingly (Ronstadt, 1987: 39; Van Clouse, 1990: 51; Ivancevich, 1991: 5; Hood \& Young, 1993: 133; Gorman et al., 1997: 15).

\subsection{Content of entrepreneurial training programmes}

Gibb (1987: 42) defines the entrepreneur and the enterprising person in terms of attributes and the small-business person in terms of 
tasks, maintaining that this should guide the development of training programmes for enterprise as opposed to training for small business owners. In their research into the distinction between entrepreneurship and small business curricula, Fregetto and Fry (2002: 11) highlight the current level of overlap between entrepreneurship and small business management courses. However, they outline clear distinctions for certain topics: the small business stream often includes many traditional management topics such as supervision, product management, human relations and procurement, while an entrepreneurship course may often include topics such as venture capital, incubators, creativity, acquisition and start-up and opportunity recognition. Nevertheless, there is a broad grey area of topic overlap, to which academic and professional experience does not provide sufficient guidance (Fregetto \& Fry, 2002: 15). Vesper and McMullan (1988: 9) emphasise two core differences between an entrepreneurship programme and the traditional management programme, namely: the ability to detect and exploit business opportunities more quickly, and the ability to project a more extensive sequence of actions for entering business. Ronstadt (1987: 45) agrees, stressing that entrepreneurial training is distinct from management education because time is vital to start-up, since it directly impacts on opportunity recognition, investigation and development, not only before but also after commencement of the venture.

In an in-depth survey of expert opinion, Hills (1988: 1) establishes that the most important educational objective of entrepreneurship programmes is to increase the learners' awareness of the processes involved in initiating and managing a new business enterprise. Other important objectives included attention to entrepreneurship as a career option, reflection on the characteristics of the entrepreneur, and understanding of functional business inter-relationships. Timmons and Spinelli (2003: xiii) promote this concept of integration between business functional areas within an entrepreneurship curriculum, and base their teaching approach on the Timmons model of the entrepreneurial process. They outline
(2003: 56) the central themes or driving forces of the dynamic entrepreneurial process. This process is:

- opportunity driven,

- guided by a lead entrepreneur and an entrepreneurial team,

- economical with resources but still creative,

- dependent on the fit and balance among the three key constructs within the model, i.e. opportunity, resources and the entrepreneurial team, and

- integrated and holistic.

This integrated approach is key to the development of training interventions for entrepreneurship, since it is significantly more organic than the content approach often associated with traditional management education. Interestingly, a survey conducted by Hood and Young (1993) of 100 chief executives in entrepreneurial firms loosely reflects Timmons' theoretical basis. Respondents were asked to identify significant skills in the four primary areas for entrepreneurial development; they mentioned leadership, communication and human relations as the most critical skill areas of knowledge, creativity and opportunistic thinking as the most important mental skill areas, selfmotivation and risk-taking as the prominent personality factors, and finance/accounting/cashmanagement and marketing/sales (along with core technical/occupational skills) as the most important content areas of knowledge (Hood \& Young, 1993: 124). Thus, entrepreneurship development requires an element of skill-building in addition to knowledge-based courses focusing on entrepreneurship. An entrepreneurial training programme must include elements such as communication skills, negotiation skills, leadership and creative thinking, authentic involvement in entrepreneurial activities, developing a portfolio of business plans, practice in opportunity identification, and exposure to entrepreneurial role models and new product development (McMullan \& Long, 1987: 268; Vesper \& McMullan, 1988: 11).

Labuschagne, Nieuwenhuizen and Kroon (2001: 18) identify the primary factors that contribute to the success of small and medium 
enterprises in South Africa, stating that the training of entrepreneurs should focus on the development of those skills and abilities identified as success factors of entrepreneurs (divided into factors directly related to personal characteristics, and those directly related to functional management skills). Empirical analysis conducted by Nieuwenhuizen and Kroon (2002: 6) shows that there is a strong relation between the success of a business and entrepreneurial success factors such as creativity and innovation, financial management, willingness to take risks, knowledge of competitors and business planning. Consequently, a training programme must focus on these entrepreneurial success factors.

\subsection{Entrepreneurship training qualifiers}

The theoretical content, and to some degree the approach, of entrepreneurial training should be checked according to certain qualifiers that optimise the programme to its specific context. These qualifiers can include, but are not limited to, the specific life cycle of the business for which the training is intended, and real-life factors such as common problems experienced by entrepreneurship practitioners. These qualifiers influence the specifics of the training content and the level at which it is presented. For instance, at a pre-entrepreneurial stage of the business, the entrepreneur as a person must be stressed, but at later stages of the life cycle the macrointernal aspects of new venture creation and the organizational creation process must be given more attention (Watson \& Boshoff, 1995: 19).

Theorists advise that entrepreneurship training be clearly distinguished from management training based on its teaching of the stage of venture development (McMullan \& Long, 1987:
268; Plaschka \& Welsch, 1990: 65). Venture development should also define the specific course structure, second only to the requirements of the specific audience (Brockhaus, 1993: 4). According to Jordaan (2002: 15), any attempt to develop entrepreneurship skills must take into account the central role of the venture life cycle, as well as of creativity and managerial competencies. The different stages of a venture are characterised by different variables which can act as moderators of the programme, determining the content and extent of any development intervention (Jordaan, 2002: 17). In the start-up phase of a venture, the problems encountered tend not to be one-dimensional but highly integrated, incapable of being solved by a single expert. It is in these situations that entrepreneurial skills are demanded, to work across boundaries on complex, interrelated problems requiring the ability to take a holistic view and exercise skills of analysis and synthesis (Garavan \& O'Cinneide, 1994: 5).

Viviers, Van Eeden and Venter (2001: 2) suggest that due to the risks associated with starting a business, educators should enhance the trainees' chances of success by directing teaching and course development towards addressing specific problem areas, so as to prepare students to better understand and anticipate the problems they will meet when entering a venture. Ligthelm and Cant (2003: 17) conducted a survey among South African owners or managers of small businesses and compiled a list of problems or issues that these practitioners view as negatively influencing the success of their small business. Table 1 contains a summary of the problems that should be considered when planning entrepreneurship training programmes.

Table 1

Problems experienced by practitioners

\begin{tabular}{|l|l|}
\hline Human resource issues & Marketing-related issues \\
- New labour laws & - Increased competition (market overtrading) \\
- Inability to attract and maintain suitable staff & - Limited market size \\
- Low labour productivity & - Ineffective marketing \\
- Poorly trained employees & - Lack of knowledge of competitors \\
- High labour turnover & - Poor location \\
\hline
\end{tabular}




\begin{tabular}{|l|l|}
\hline Management functions & Macro-environmental issues \\
- Adapting to changing business environment & $\bullet \quad$ Crime and corruption \\
- Time management & $\bullet \quad$ Inflation \\
- & $\bullet \quad$ Unemployment (limited market) \\
- Effective control & $\bullet \quad$ Interest rates \\
\hline Financial issues & $\bullet \quad$ Exchange rates \\
- Difficulty in obtaining finance/credit & \\
- Heavy operating expenses & \\
- Management of consumer credit & \\
- Poor cash flow management & \\
\hline$\quad$ Lack of financial planning & \\
\hline
\end{tabular}

Source: Ligthelm and Cant, (2003)

\subsection{Approach to training delivery}

Entrepreneurship as a subject is globally seen as an applied science. It therefore requires a more practical training approach than traditional teaching methods usually offer (Antonites \& Van Vuuren, 2004: 4). Nieuwenhuizen and Groenewald (2004: 4) suggest a training methodology based on brain preference. By their very nature, individuals who express entrepreneurial intentions tend to show psychological traits that differ from those of non-entrepreneurs, and therefore tend to prefer active learning styles. In a similar vein, Ulrich and Cole (1987: 35) examine the importance of learning style preferences in enhancing trainees' learning experience and entrepreneurial propensity, and conclude that entrepreneurial learning style preferences tend toward active experimentation with some balance between concrete experience and abstract conceptualisation.

Pretorius (2000: 3 ) proposes the concept of an entrepreneurial-directed learning approach, which aims to deliver the highest level of knowledge transfer and mastery of execution through experiences that lead to relatively permanent changes in behavior. Amos and Maas (2001: 1) support this view that the emphasis in education should be on what entrepreneurs need to do and not on the characteristics that describe what they are. These scholars stipulate that educators need to understand the requirements of entrepreneurial success, and thereby develop a complex understanding within learners by exposing them to the world of business, and developing their ability to deal with ill-structured problems. Klandt (1993: 43) further proposes that within the constructs of the entrepreneurial personality and the entrepreneurial task, consulting activities, working with entrepreneurs and business simulations are very useful teaching and learning methods for the entrepreneurship education target audience. Although it is important to facilitate theoretical knowledge acquisition and retention, the necessary cognitive skills must also be developed to enable a learner to start up and manage a business organisation. The ideal entrepreneurial-directed approach is one requiring the instructor to become a learning facilitator. Such an approach entails extensive use of learning exercises such as role playing, management simulations, structured exercises of focused learning and feedback situations in which the participant must take an active role (Nieuwenhuizen \& Groenewald, 2004: 5).

An empirical study conducted by Antonites and Van Vuuren (2004: 1) illustrates the effectiveness of an action learning approach applied to training in creativity, innovation and opportunity identification. Action learning is the result of a combination of experiential learning, creative problem solving, acquisition of relevant knowledge and co-learner group support. 
Gartner and Vesper (1994: 185) conducted a survey into experimental approaches to entrepreneurship education, and report as failures those processes that require students to engage in introspective or reflective activities or to develop case-lets, and as highly successful exercises such as the development of business plans for products. Similarly, a survey by Hills (1988: 2) of expert opinion established that course features considered most important are the development of a business plan project and entrepreneurs as speakers and role models.

\subsection{The entrepreneurial performance education model}

As mentioned above, Van Vuuren and Nieman (1999: 3) propose a multiplicative training model:

$$
\mathrm{EP}=\mathrm{M}(\mathrm{ES} \times \mathrm{BS})
$$

also referred to as the entrepreneurial performance education model (Pretorius, Nieman \& Van Vuuren, 2005: 420). This model differs from the typical "small business management" approach to entrepreneurship training, which generally focuses primarily on business skills (BS), by introducing entrepreneurship skills (ES) (such as creativity, opportunity identification, ability to take risks etc.) and motivation development (M).

The positive effects of achievement motivation training on entrepreneurial activity are well recorded (McClelland, 1965b; Timmons, 1971; Miron \& McClelland, 1979), although a definitive link between achievement motivation and entrepreneurial success has not been established (Johnson, 1990: 1). However, achievement motivation is seen as perhaps the only person-based variable whose association with new venture creation still appears to be convincing (Shaver \& Scott, 1992: 9). Motivation plays a strong role in an individual's taking action (McClelland \& Winter, 1971: 234), and so is extremely relevant to any training initiative which aims to create new businesses, since no amount of training effort or student intent can be successful without meaningful action towards implementation.

Pretorius (2000: 5) proposes a training methodology which he calls the entrepreneurship education model (EE model), which is based on:
- a framework of known entrepreneurial success factors,

- other content pertaining to business knowledge and skills, approaches to business learning, the business plan and the facilitator, and

- the overall context of the programme.

The focus of this EE model is increasing the number of new business start-ups (Pretorius et al., 2005: 423). The business knowledge content must include a range of entrepreneurship and business-related knowledge, as dictated by the needs of the target audience or situation. The three foundations of the model come together in the business plan, which is the integration of all the elements that determine the likelihood of future business success. According to Botha (2006), no meaningful business training can be effected without involvement in the creation of a business plan. Of course, the successful delivery of the training depends on the facilitator's particular approach to facilitation and learning, and on his/her ability and level of real-world entrepreneurship experience.

Although Van Vuuren and Nieman's EP model (1999) and Pretorius's EE model (2000) contribute greatly towards our model's paradigm of entrepreneurship training, they both have certain shortcomings. The motivation element is absent from the EE model, while the EP model does not factor in the facilitator's approach to training, the role of the facilitator, the context of the training or the use of a business plan (although this is arguably included in the BS factor).

Thus to correct these limitations, Pretorius et al. (2005: 422) propose a model that integrates the aspects of the two philosophies, education and entrepreneurial performance. This integrated model called the educate for entrepreneurial performance (E for EP) model, can be expressed as follows:

$$
\begin{aligned}
& \mathrm{E} \text { for } \mathrm{EP}=f[\mathrm{aF} \times \mathrm{bM}(\mathrm{cES} \times \mathrm{dBS}) \times(\mathrm{eA} \\
& +\mathrm{fBP})]
\end{aligned}
$$

where:

$$
\begin{aligned}
\mathrm{E} \text { for } \mathrm{EP}= & \text { education for improved entre- } \\
& \text { preneurial performance } \\
\mathrm{F} \quad & \begin{array}{l}
\text { facilitators ability, skills and } \\
\text { experience }
\end{array}
\end{aligned}
$$




$\begin{array}{ll}\mathrm{M} & =\text { motivation } \\ \mathrm{ES} & =\text { entrepreneurial skills } \\ \mathrm{BS} & =\text { business skills and knowledge } \\ \mathrm{A} & =\text { approaches of learning used } \\ \mathrm{BP} & =\text { use of a business plan as a training } \\ & \text { approach } \\ \mathrm{a}-\mathrm{f} & =\text { constants }(0>\text { constant }<1)\end{array}$

This integrated model aims to lead to real behavioural and attitudinal change within the participants who complete the training programme. In addition to key theoretical and motivational training content, this model's unique contribution is its inclusion of the type of training approach used by the facilitator as dictated by the specific context of the programme, and of the overall skill and experience level of the facilitator (Pretorius et al., 2005: 422). The training approaches that are most successful are practical programmes involving the actual starting of new ventures or creation of business plans, simulations and case studies.

\subsection{Relevance to South Africa and other developing countries}

Developing countries face enormous challenges. High unemployment levels, poor education and low literacy rates, critical skills deficits, and a large divide between rich and poor are but a few of these. Improving the quality of life of previously disadvantaged communities is intimately associated with enabling individuals to take control of their circumstances on the one hand, and raising their employability on the other (Maminza et al., 2001). Entrepreneurship underpins both of these effects, and the drive by the government and local municipalities to raise the quality of life for disadvantaged communities is increasingly centred on the development of entrepreneurship orientation and skills, and building an enabling environment to facilitate entrepreneurial activity. McClelland and Winter (1971: 28) indicate that where the level of entrepreneurship is low, development programme officers may be driven to such extraordinary costs in providing incentives that programmes may be jeopardised. If the structure of the response is inappropriate, any manipulation of incentives will incur enormous waste. The situation can be significantly improved if incentive programmes are accompanied by appropriate training initiatives.

McMullan and Long (1987: 1) view entrepreneurship education as an essential part of job creation, since this education is an integral component of a community's venture-support infrastructure along with incubators, innovation centres, technology transfer offices, science parks and venture capital operations. Since success in a new business endeavour is ultimately dependent on the level of entrepreneurial knowledge, experience and self-confidence of the entrepreneur, entrepreneurship education may be the most promising of all current economic development mechanisms, although arguably the most difficult to implement. For this reason, efforts to better understand the tools and mechanisms of effective entrepreneurship training can usefully facilitate targeted training interventions and the implementation of appropriate economic development policies.

\section{7}

\section{Case programme evaluation}

\subsection{Context of the NVCL training programme}

Subject knowledge elements are required in an entrepreneurship curriculum, and the level of complexity at which they can be presented is determined by the context of the training programme (Pretorius, 2001). The context elements that should be included, from the field of small business entrepreneurship, are:

- previous experience level of participants at the start of training,

- educational level of participants,

- outcomes to be achieved on completion of the training (start-up vs knowledge for example),

- reason for participation in the training and

- needs of the target group undergoing the training

The NVCL strategy specifically mentions that the learnership programme aims to develop 
young people (Department of Labour, 2005: 17). Davies (2002: 15) describes the profile of the learnership candidates and their latent level of skills and experience as follows:

Given that all applicants for the Venture Creation Learnership programme will be mature and will probably have had business exposure (as employees), the assumption exists that their technical skills base would be reasonably well developed; that their business skills base will be higher than for a group of pre-employed candidates; and that their educational fundamentals (given that most candidates in this programme would have at least 9 years of schooling) would be reasonably high. It could be equally assumed that in terms of self-knowledge and attitudinal disposition towards entrepreneurship, the level of exposure and knowledge would be low, requiring a good deal of attention in the programme to changing the mindset of learners.

It is important to stress that pre-employment does not disqualify currently unemployed people, a demographic which is a key target of the learnership intervention (Davies, 2000: 1). However, the selection process must assess their level of education, underlying skills base and level of life-skills as fundamental entry criteria. Timmons and Spinelli (2003: 259) refer to a pattern of experience often seen among successful entrepreneurs, which resembles an apprenticeship; this experience encompassing experience, know-how, contacts and market knowledge, and is acquired gradually over a long period. Applicants for the learnerships, whether currently employed or unemployed, who lack fundamental educational, literacy-related, life or vocational skills will face significant challenges in new venture creation, and are viewed as unsuitable candidates for the learnership or other such interventions. If the measured outcome of an intervention is tangible business creation, a learner selection strategy that ignores these factors will jeopardise the programme's overall performance.

Accordingly, a screening process must be used in the selection of candidates, to make sure that those selected possess the requisite degree of life experience and vocational skills and experience. The focus of the NVC curriculum should therefore primarily be geared towards the development of an entrepreneurial mindset and associated entrepreneurship and business skill sets, not vocational skills or fundamental education elements such as literacy and numeric skills. Vocational/technical training cannot feasibly form part of an entrepreneurship course, since trainees will be involved in a wide range of industries and fields, all of which cannot be covered in one course. In cases where learners need to develop business ideas that are dependant on technical skills they do not possess, development in these areas can be provided via links with colleges and specialist private institutions.

\subsection{Assessment framework}

Ladzani and Van Vuuren (2002: 156) illustrate the application of the EP model as a basis for assessing training programmes offered by various training service providers. In their study, the fundamental elements of entrepreneurship training highlighted are Management Skills, Opportunity Identification, Business Plan, and Need for Achievement. In our E for EP model, these same fundamental elements are also the basis for assessment, although the context of each individual training intervention will dictate the inclusion of various other elements outlined in the EP model.

To assess Proposition 1, we use a framework designed to assess the NVCL course content. Table 2 outlines this framework, which is based on various literature sources and shaped by the factors highlighted in the EP model, i.e. M, ES and BS. The NVC qualification unit standards, which consist of fundamental, core, and elective modules, were evaluated against these content guidelines. The fundamental modules, which deal with English literacy and basic numeracy, were excluded from the analysis, for reasons outlined above in our discussion on the context of the NVCL initiative and the appropriate learner profile for the programme. Elective modules are viewed as supplementary components and not core teaching on entrepreneurship fundamentals, and so also excluded from the 
assessment. Thus only the core modules were selected for assessment against the evaluation framework. Proposition 2 was assessed according to the criteria outlined in Table 3 , as explained in the methodology section.

\section{Table 2}

Training content components

\begin{tabular}{|c|c|c|}
\hline Motivation & Entrepreneurial skills & Business skills \\
\hline $\begin{array}{l}\text { Need for achievement } \\
\text { - } \text { Achievement imagery } \\
\text { - } \text { Achievement goals } \\
\text { - } \quad \text { Language of achievement } \\
\text { - } \quad \text { Cognitive supports } \\
\text { - } \quad \text { Group supports }\end{array}$ & $\begin{array}{l}\text { Creativity } \\
\text { - } \text { Techniques } \\
\text { - } \text { Critical vs creative thinking } \\
\text { - } \quad \text { Personal attributes and } \\
\text { actions that facilitate creativity } \\
\text { - Intuitive ability }\end{array}$ & $\begin{array}{l}\text { Management/Leadership } \\
\text { - } \text { Planning } \\
\text { - } \text { Organising } \\
\text { - } \text { Leadership } \\
\text { - } \text { Control }\end{array}$ \\
\hline Ability to inspire & Innovation & Business plans \\
\hline $\begin{array}{l}\text { Expectations of the high } \\
\text { achiever } \\
\text { - } \quad \text { Thoughts on probability of } \\
\text { personal success } \\
\text { - } \quad \text { Expectation of success } \\
\text { - } \quad \text { Fear of failure } \\
\text { - } \quad \text { Motivation to excel }\end{array}$ & $\begin{array}{l}\text { Ability to take risks } \\
\text { - } \quad \text { Financial } \\
\text { - } \quad \text { Career-related } \\
\text { - } \quad \text { Family- and social-related } \\
\text { - } \quad \text { Psychological } \\
\text { - } \quad \text { Tolerance for risk and } \\
\text { ambiguity }\end{array}$ & $\begin{array}{l}\text { Financial skills (for pre-venture } \\
\text { and infancy stages) } \\
\text { - } \quad \text { Start-up planning } \\
\text { - } \quad \text { Cash flow budget } \\
\text { - } \quad \text { Break-even analysis } \\
\text { - } \quad \text { Short-term planning } \\
\text { - } \quad \text { Working capital management } \\
\text { - } \quad \text { Sources of finance } \\
\text { - } \quad \text { Record keeping. }\end{array}$ \\
\hline $\begin{array}{l}\text { Obstacles or blocks } \\
\text { - Awareness of personal } \\
\text { obstacles } \\
\text { - Awareness of obstacles in the } \\
\text { environment }\end{array}$ & $\begin{array}{l}\text { Ability to identify opportunities } \\
\text { - } \quad \text { Generation of ideas } \\
\text { - } \text { Prioritisation of ideas } \\
\text { - } \text { Opportunity delineation } \\
\text { - Opportunity evaluation }\end{array}$ & $\begin{array}{l}\text { Marketing skills } \\
\text { - Understanding the customer } \\
\text { - } \text { Market size } \\
\text { - } \quad \text { Competition awareness } \\
\text { - } \quad \text { Pricing and sales tactics }\end{array}$ \\
\hline $\begin{array}{l}\text { Help } \\
\text { - Towards reaching the } \\
\text { achievement goal } \\
\text { - Thinking beyond obstacles }\end{array}$ & $\begin{array}{l}\text { Ability to have a vision for } \\
\text { growth } \\
\text { - Commitment to growth }\end{array}$ & $\begin{array}{l}\text { Operational skills } \\
\text { - Methods enhancing } \\
\text { productivity (product or } \\
\text { service business) }\end{array}$ \\
\hline $\begin{array}{l}\text { Reaction to success or failure } \\
\text { - } \quad \text { Response to feelings of failure } \\
\text { (seen as a reason to try again) }\end{array}$ & $\begin{array}{l}\text { Interpret successful } \\
\text { entrepreneurial role models } \\
\text { - } \quad \text { Entrepreneurial characteristics }\end{array}$ & $\begin{array}{l}\text { Human resource skills } \\
\text { - Planning } \\
\text { - } \quad \text { Compensation } \\
\text { - Training } \\
\text { - Management }\end{array}$ \\
\hline
\end{tabular}




\section{Table 3}

Constructs pertaining to training execution

\begin{tabular}{|c|c|}
\hline Factor & Considerations \\
\hline $\begin{array}{l}\text { Context of the } \\
\text { programme }\end{array}$ & $\begin{array}{l}\text { - Previous experience of the participants } \\
\text { - Minimum educational level of the participants } \\
\text { - Outcomes of the programme after participation } \\
\text { - Needs of the target group who participate in the programme } \\
\text { - } \text { Reasons for participating in the programme }\end{array}$ \\
\hline $\begin{array}{l}\text { Business knowledge } \\
\text { and skills }\end{array}$ & $\begin{array}{l}\text { - Perceiving an opportunity and developing a business concept } \\
\text { - Starting a business venture from the business plan } \\
\text { - Growing the business venture after start-up } \\
\text { - Competing in a mature market through effective and efficient strategies } \\
\text { - Exiting the market in a decline phase through successful divestment strategies }\end{array}$ \\
\hline Facilitator & $\begin{array}{l}\text { - } \\
\text { - } \text { Developing entrepreneurial thinking patterns } \\
\text { - } \text { Apprenticeship and mentoring through venture establishment } \\
\text { - Application of a holistic and multi-disciplinary approach } \\
\text { - } \text { Own level of practical experience with start-ups }\end{array}$ \\
\hline $\begin{array}{l}\text { Approaches used to } \\
\text { transfer knowledge } \\
\text { and skills }\end{array}$ & $\begin{array}{l}\text { - Use of appropriate approaches, techniques and methods that enhance learning } \\
\text { - Optimal participation of the learner in the learning process } \\
\text { - Incorporation of real-life problems and obstacles in the learning process }\end{array}$ \\
\hline $\begin{array}{l}\text { Business plan } \\
\text { utilisation }\end{array}$ & $\begin{array}{l}\text { - Preparation of a business plan } \\
\text { - Presentation of the business plan to peers, facilitators and potential funding } \\
\text { institutions } \\
\text { - Opportunity to defend the main principles and assumptions underlying the plan } \\
\text { against critical evaluation } \\
\text { - Execution of the business plan under real circumstances }\end{array}$ \\
\hline
\end{tabular}

Source: Pretorius (2001).

8

\section{Findings and discussion}

Currently, there is no standard approach to the facilitation of NVC learnerships among those service providers involved in the initiative. Furthermore, apart from the guidelines provided by SAQA for the required outcomes of the learnership, very little literature is available which outlines possible approaches for providers in enough detail to make assessment worthwhile for the purposes of this study. For these reasons, our analysis is restricted to the activities and achievements of a single programme, the
Provincial Skills Development Pilot Project Phase II, which is presented by the Support to Education and Skills Development (SESD) initiative.

Phase II of the Provincial Skills Development Pilot Project began in 2000. Its objective is the implementation of learnerships and skills programmes aimed at people with the potential to start, manage and grow their own businesses. According to Davies (2000: 1), the Pilot Project aims to support the Department of Labour in securing employment for people from vulnerable groups through:

- developing their employable competencies, 
- making recommendations on guidelines and procedures for nation-wide implementation of learnerships and skills programmes as instruments for assisting the unemployed to become entrepreneurs in the South African sector of small and micro enterprises, and

- building capacity in the Provincial Office of the Department of Labour (and among training and service providers) to implement such strategies.

A key focus area is the establishment of small- and micro-enterprise employment for unemployed, newly retrenched, or soon-to-be retrenched persons with entrepreneurial skills, as part of the Department of Labour's response to Social Plans, by means of an integrated learnership approach.

\subsection{Assessment findings for proposition 1: the course content of the NVCL}

The NVC qualification outcomes were analysed against the criteria stipulated in the evaluation framework for curriculum content. In particular, the outcome statements and the assessment criteria for each core unit standard were examined, to understand the prospective content of each module. Since all learnership activities should be guided by these unit standards, the actual teaching materials used by facilitators were assumed to have been developed in accordance with these standards and so were not themselves assessed. The evaluation was conducted by means of a comparison template, which included each of the business-, entrepreneurial- and motivational-skill areas outlined in table 2, compared with the unit standard titles, outcome statements and assessment criteria (refer to example in table 4). The assessment criteria provided the richest source of information about the intent of each training component, since they stipulate the manner in which the eventual learner competencies must be assessed.

\section{Table 4}

Example of the comparison template

\begin{tabular}{|c|c|c|}
\hline $\begin{array}{l}\text { Entrepreneurial } \\
\text { skill: }\end{array}$ & \multicolumn{2}{|c|}{$\begin{array}{l}\text { Associated Unit Standard: } \\
\text { Research the viability of new venture ideas/opportunities }\end{array}$} \\
\hline Suggested content & Specific outcomes & Assessment criteria \\
\hline Generation of ideas & $\begin{array}{l}\text { SPECIFIC OUTCOME } 1 \\
\text { Identify and assess own } \\
\text { business ideas/opportunities for } \\
\text { a new venture }\end{array}$ & $\begin{array}{l}4 \text { assessment criteria e.g. } \\
\text { - Sources and methods of access to general and } \\
\text { commercial business information are identified } \\
\text { for proposed business venture. }\end{array}$ \\
\hline $\begin{array}{l}\text { Prioritisation of } \\
\text { ideas }\end{array}$ & $\begin{array}{l}\text { SPECIFIC OUTCOME } 2 \\
\text { Analyse the viability of a } \\
\text { selected idea/opportunity against } \\
\text { specific screening variables }\end{array}$ & $\begin{array}{l}4 \text { assessment criteria e.g. } \\
\text { - Access to relevant technology and other } \\
\text { resources needed for the new venture is } \\
\text { analysed to aid a decision on the viability of } \\
\text { the new venture. }\end{array}$ \\
\hline $\begin{array}{l}\text { Opportunity } \\
\text { delineation }\end{array}$ & $\begin{array}{l}\text { SPECIFIC OUTCOME } 3 \\
\text { Research the potential of a } \\
\text { particular idea/opportunity as a } \\
\text { new venture }\end{array}$ & $\begin{array}{l}5 \text { assessment criteria e.g. } \\
\text { - Market research is conducted including } \\
\text { analysis of demand for the product/service and } \\
\text { competitor analysis. }\end{array}$ \\
\hline
\end{tabular}




\begin{tabular}{|l|l|l|}
\hline $\begin{array}{l}\text { Opportunity } \\
\text { evaluation }\end{array}$ & $\begin{array}{l}\text { SPECIFIC OUTCOME 4 } \\
\text { Analyse a range of risks } \\
\text { associated with a new venture } \\
\text { SPECIFIC OUTCOME 5 } \\
\begin{array}{l}\text { Evaluate new venture ideas/ } \\
\text { opportunities based on research } \\
\text { findings }\end{array}\end{array}$ & $\begin{array}{l}5 \text { assessment criteria e.g. } \\
\text { The potential risks and factors that may } \\
\text { threaten the new venture are identified and } \\
\text { analysed with a view to eliminating and/or } \\
\text { minimising them. }\end{array}$ \\
& $\begin{array}{l}\text { 2 Assessment criteria e.g. } \\
\text { A preliminary evaluation of the proposed new } \\
\text { venture is produced in the form of a written } \\
\text { report, using the identified criteria. }\end{array}$ \\
\hline
\end{tabular}

The findings can be summarised as follows:

- The curriculum covers the fundamental business skills very well. All business skills outlined within the framework are represented, and the fundamental business skill elements highlighted by Ladzani and Van Vuuren (2002: 158), i.e. managerial skills and the business plan, are well covered. The programme also covers other business skills not represented in the evaluation framework, such as ethics, quality policies, time management, mobilising resources, negotiation and tendering procedures. These skills reflect the programme's unique contextual requirements.

- Similarly, the entrepreneurial skills are covered relatively well, with separate unit standards focusing on Creativity and Innovation and Opportunity Identification. The Entrepreneurial Profile is discussed, with reference to the characteristics of a successful entrepreneur, and learners assess their individual entrepreneurial characteristics with the aim of improving these. Some reasons for business failure are identified and discussed with the aid of examples. However, these only include business risks, and no discussion or evaluation of personal propensity towards risk taking is covered.

- Achievement motivation is poorly represented in the curriculum. Although goal setting is mentioned, it is not explicitly linked to achievement motivation. Cognitive and psychological factors such as personal mental obstacles, achievement imagery and goals, and reaction to success or failure are not covered at all. Since the likelihood of new venture initiation is heavily dependent on the ambition and cognitive state of the prospective entrepreneur, the relative absence of achievement development is the foremost shortcoming of this curriculum.

- The present structure of the curriculum's content suggests that the programme is geared towards the growth stage of a venture's life cycle, instead of the pre-start and start-up phases. This is best illustrated by the curriculum's treatment of financial content, which is relatively complex. Other assessment standards focus on advanced control methods such as quality assurance and productivity optimisation, which are also suited to the growth stage. We would thus suggest that this content be postponed to a second phase of training, once the new venture has been established and nurtured through its infancy stage. However, these unit standards do have a place within this specific programme, since it aims to provide a holistic view of small business development, not just start up.

- Although real-life problems are not covered explicitly in the assessment criteria, all of the problems mentioned in section 6.3 of this study are included indirectly in discussions of related content. Future revisions of unit standards could include specific references to the problems commonly faced by small businesses.

\subsection{Assessment findings for proposition 2: training delivery}

Training delivery was evaluated using a questionnaire based on the entrepreneurial training (EE) model proposed by Pretorius (2001: 264). An additional element was included in addition to the learning approach focus of 
this model, to evaluate the treatment of reallife problems within the programme being investigated. The results of this qualitative evaluation are presented as radar diagrams, with each of the elements within a construct represented by a node on the diagram. The average value of the results for each element in the feedback from the questionnaire is represented on the scale for that element node. Any significant deviations from the scale median value of 4 represent either positive or negative aspects of the programme. Important deviations are discussed.

\subsubsection{Key issues concerning the context of the learning programme}

Figure 1 illustrates the results of the in-depth evaluation of the learning programme. Although the selection requirements are clearly stated in the programme's selection criteria (Department of Labour, 2003: 4), they do not seem to be applied in practice, since the target group's previous experience levels, needs and reasons for participation seem to be specific problem areas, with all three elements scoring below the median. An inconsistency is evident between the context of the NVCL programme (as outlined earlier) and aspects of the selection process. A review of candidate characteristics and opinion reveals that some candidates were recruited directly following secondary school (e.g. almost 30 per cent of KZN candidates), and only 34 per cent of all candidates could cite specific examples of previous experience in running a business (Prodigy, 2005: 5). Furthermore, approximately half of the candidates reported that they would prefer formal employment, or would prefer gaining more work experience before starting their own business (Prodigy, 2005: 7). These points indicate that the candidate selection may not have targeted the right type of individual in some cases.

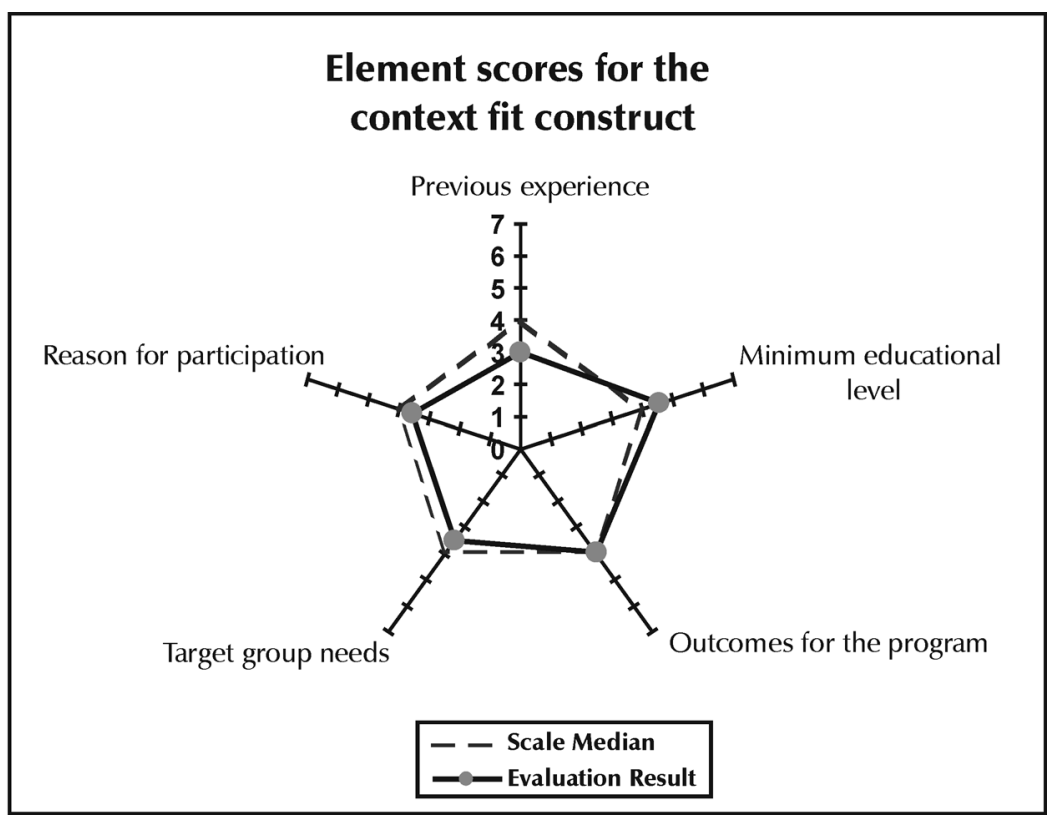

Figure 1

Graphical representation of evaluation results for the elements of the context fit of the NVCL compared to the midpoint 
Two possible reasons for this can be suggested:

- In some cases, limited practical business experience among selectors, and consequent inexperience in identifying entrepreneurial potential results in circumvention of selection requirements. Thus, some learners are granted admission to the programme who are not suited to the demands of the NVC initiative.

- Secondly, for some learners, the allowances are more than they are accustomed to having in their hands (New Venture Africa, 2005: 25). This generates the problem of learners becoming reliant on such monies, or entering the programme primarily because of the allowance rather than because they want to establish a business. Hence, the selection process must place greater emphasis on targeting and correctly identifying candidates with the right entrepreneurial attributes, and ensuring that their motivation is not driven by the monetary incentives of learner allowances.

\subsubsection{Key issues in the entrepreneurial success themes construct}

As Figure 2 illustrates, the elements of this construct are covered relatively well, especially within the instructional unit standards. However, the programme struggles to instil tolerance for calculated risks, management of stress and conflict, and the ability to deal with uncertainties.

It was highlighted that though the programme covers these aspects in the innovation and entrepreneurial profile modules, they are not addressed as a salient facet of the programme. The respondents suggested that focus on these factors largely depended on the individual facilitator's practical business experience and specific approach to training. These characteristics are thus least well developed among students trained by facilitators with a purely theoretical background.

\section{Element scores for the entrepreneurial success themes construct}

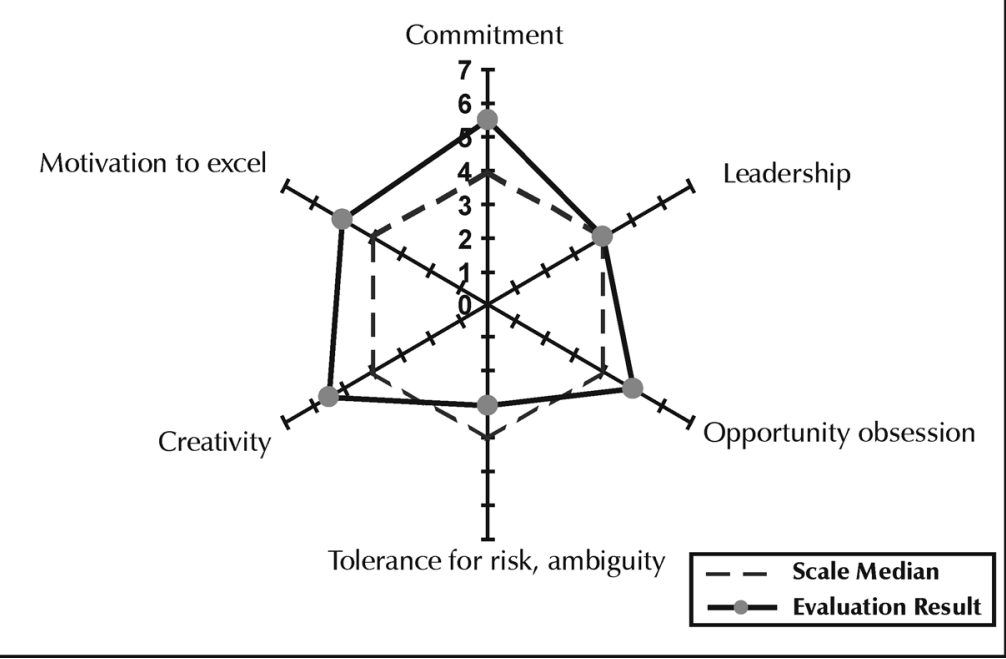

Figure 2

Graphical representation of evaluation results for the elements of the entrepreneurial success construct of the NVCL compared to the midpoint 


\subsubsection{Key issues in the business knowledge and skills construct}

Since the focus of the programme is on business start-ups, the development and start-up phases of a project's life cycle are covered well. The technical skills of running a business are also covered in great detail within the instructional unit standards. Figure 3 highlights a shortfall in skills required for bridging the gap between start-up and maturity, i.e. the ability to grow a business. The theory of business growth is covered in the "Developing your business" module, but significant growth development falls outside the intervention frame, i.e. the initiative is aimed at start-up and early growth. Further development instruction is not provided in the learning materials, but should be offered through continued mentoring support and an ongoing relationship with the training providers.
However, this bridging infrastructure is no longer in place, and only lending institutions provide assistance to recipients of formal loans.

The results are consistent with the context of the NVCL programme (i.e. fostering entrepreneurial intent among candidates, and starting-up of new ventures), and with its focus on the start-up phase of the life cycle as a content qualifier. Therefore, the strong emphasis on the development and start-up phases is a positive attribute of this programme.

The decline phase is not formally covered in the programme, but this is not considered a serious limitation for a course whose primary objective is business initiation and development. However, knowledge about failure would enhance the learners' understanding of the direct environment in which ventures operate.

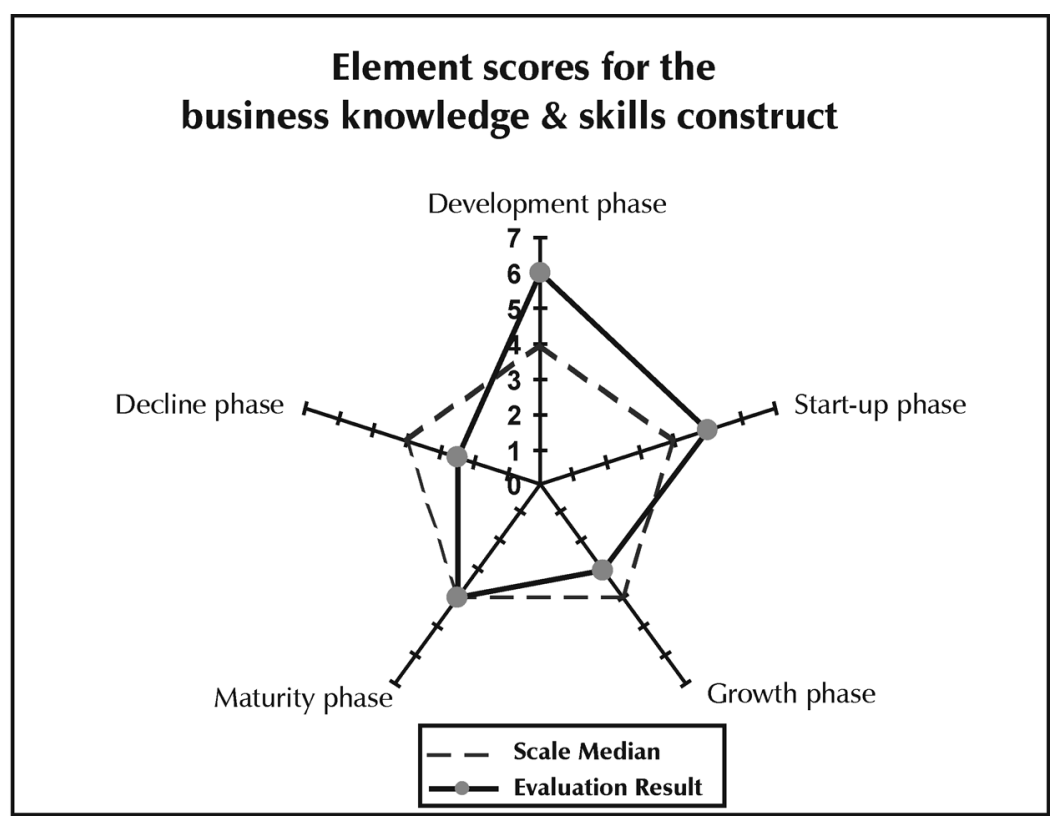

\section{Figure 3}

Graphical representation of evaluation results for the elements of the business knowledge and skills construct of the NVCL compared to the midpoint

\subsubsection{Key issues in the learning approaches construct}

The programme is experiential in nature, and uses the development of a tangible business as the learning medium. The assessment criteria for the institutional learning component frequently refer to evidence of skills application within the learner's own venture. The learning process also incorporates mentorship and access to markets for viable business plans (Le Roux, 
2004: 14). The creation of a new venture as an exercise in entrepreneurship is arguably the most powerful possible training approach, which is also in line with the strategic intent of the NSDS. However, Figure 4 clearly shows that the programme lacks appropriate techniques for effectively preparing learners for creating their own ventures, techniques such as simulations, case studies and decisionmaking models. As outlined in the literature review, the emphasis in education should be on what entrepreneurs need to do and not on the characteristics that describe what they are. An approach lacking in practical (or simulated) application and experiential learning may significantly limit the success of the programme.
This limitation is largely due to the nature of the learning materials used by the training providers. The initial set of materials (which has subsequently been rewritten) provided no clear direction for the learning path, and no module linkages to unit standards or outcomes to be achieved. Instead, the materials focused on theory, with limited opportunities for practical exercises and experiential learning. Such limitations can of course be overcome by improvisation on the part of the individual facilitator, but a lack of business experience limits this in some cases. Ideally, the theoretical and practical elements should run concurrently, with candidates assimilating theoretical knowledge while conducting research and compiling business plans related to their own business.

\section{Element scores for the learning Approaches construct}

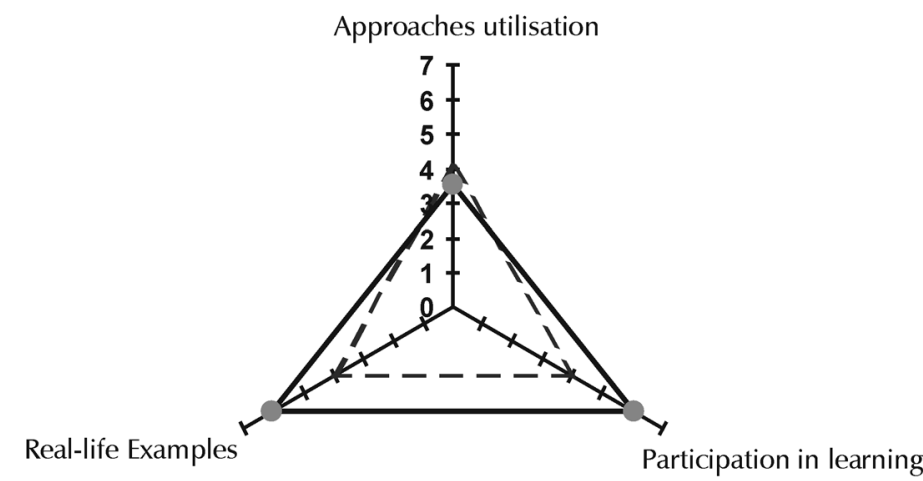

- - Scale Median

—_ Evaluation Result

\section{Figure 4}

Graphical representation of evaluation results for the elements of the learning approaches construct of the NVCL compared to the midpoint

\subsubsection{Key issues in the business plan utilisation construct}

As outlined in Figure 5, all aspects are covered well and actually using a business plan is a key focus of the training executed in the programme.
This is a critical element, as we discussed in the literature review, since no meaningful business training can be effected without students' being involved in creation a business plan (Botha, 2006). 


\section{Element scores for the business plan utilisation construct}

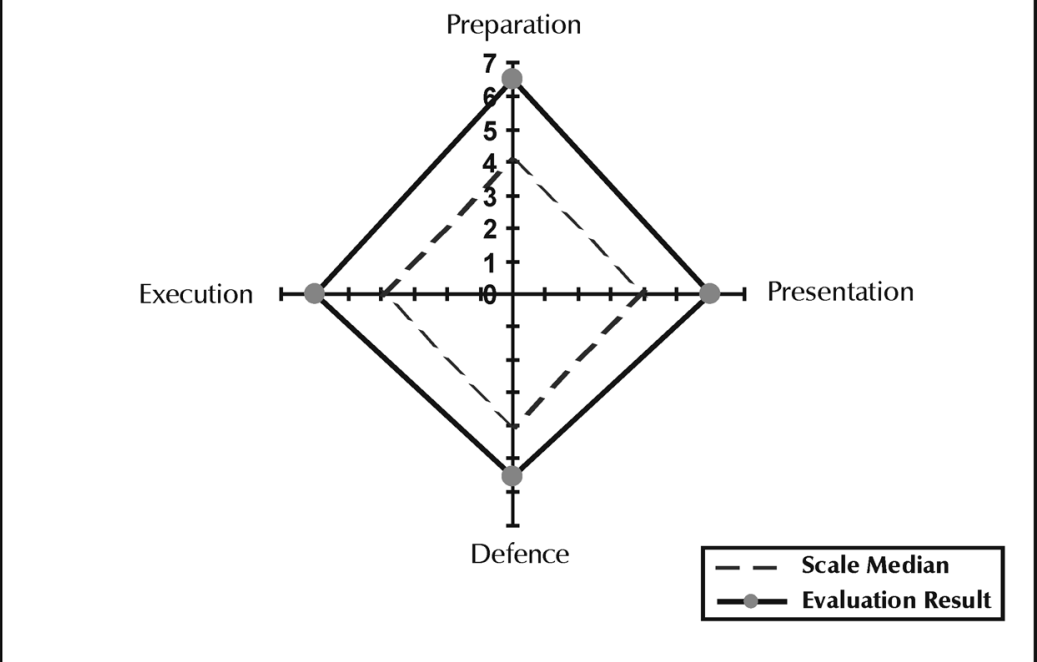

Figure 5

Graphical representation of evaluation results for the elements of the business plan utilisation construct of the NVCL compared to the midpoint

The focus of the institutional learning component is the development and submission of the business plan. Learners are assessed against the viability of their business plans, and have to leave the programme if their business plans are not approved (Le Roux, 2004: 12). A notable finding was that while many learners start with grand but unfeasible visions for potential businesses (e.g. involving extensively high leverage, limited markets etc.), the business planning process effectively helps them to narrow these aspirations down to more workable and realistic business models.

\subsubsection{Key issues in the facilitator construct}

The results indicate that, in general, the facilitators are suitably experienced and able to present the training in a manner that brings about actual change in the learners' ability to start successful business ventures (see Figure 6). A notable exception is those facilitators with little practical business experience who rely on a purely theoretical approach; their students are less inclined to initiate businesses on their own. In some cases intervention was needed to prompt students towards business activities, and allow them to make the crucial links between theory and business practice.

This poses a challenge to entrepreneurship development programmes, the success of which is dependent on the approach, delivery and real-world entrepreneurship experience of its facilitators, as discussed in the literature review. Unfortunately, it is not always easy to find entrepreneurially inclined and/or experienced individuals who are prepared to facilitate such courses. The situation may be improved by developing well structured facilitator guides for facilitators who lack experience. These could be checked by experienced entrepreneurs, and should include detailed experiential activities and course delivery guidelines.

\subsubsection{Overall programme evaluation}

The results in Figure 7 reflect a generally positive perception among NVC learnership practitioners of the various aspects of the programme. However, the context fit and business knowledge and skills constructs show up as the weaker areas of the programme, with scores of 3.7 and 4.1 respectively. 


\section{Element scores for the facilitator construct}

Reinforced thinking

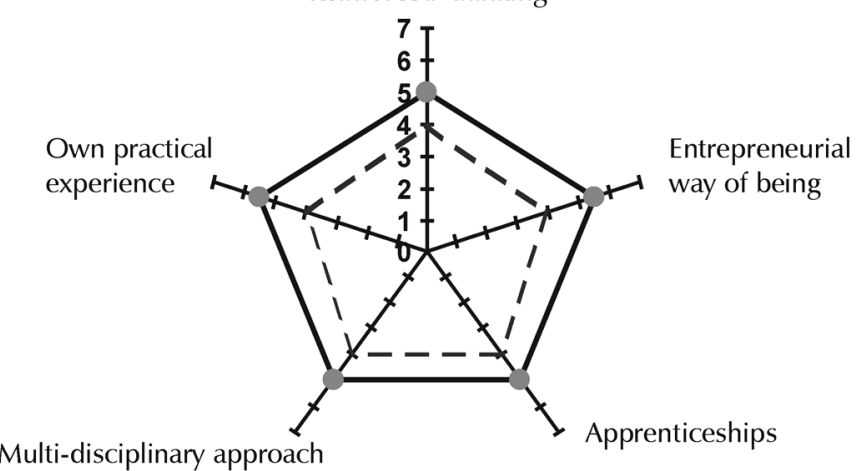

Multi-disciplinary approach

- - Scale Median

- Evaluation Result

\section{Figure 6}

Graphical representation of evaluation results for the elements of the facilitator construct of the NVCL compared to the midpoint

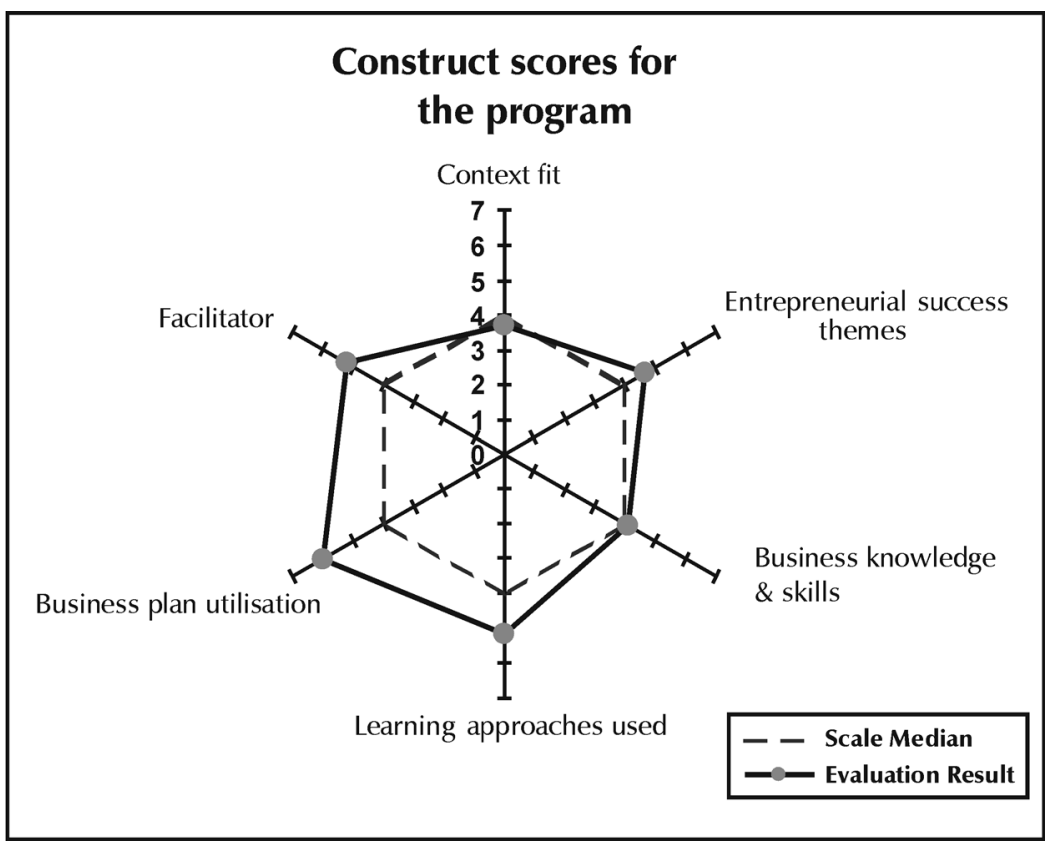

\section{Figure 7}

Graphical representation of evaluation results for the overall NVC learnership programme of the NVCL compared to the midpoint 
The content and training approach of the SESD initiative is thus found generally to be achieving the outcomes set by the NSD strategy. The initiative's experiential approach to training is a very strong characteristic of the programme. Involving the actual start-up of a real business venture in the learning process is in line with the strategic intent of the NSDS.

A key weakness of the programme is the high learner attrition rate, with a drop of 33 per cent from 85 to 57 learners between November 2004 and November 2005 (Prodigy, 2005: 7). This may be partly due to the mismatch between programme context and learner selection, as we have discussed. Of those learners that remain, 42 per cent have decided on their businesses and 58 per cent have either clients on board and are generating income and/or have started employing staff (Prodigy, 2005: 55).

Apart from the curriculum and training delivery limitations we have discussed, the programme shows some administrative and logistical shortcoming; these however fall outside our evaluation here. The programme also shows certain limitations when evaluated against the evaluation framework. The most important of these limitations are:

- the omission of achievement motivation development from the course,

- the compromising of suitable training approaches by inadequate training materials and inexperience of facilitators in certain cases,

- the mismatch between the context of the programme and actual learner selection, which jeopardises the programme's overall performance potential.

Consequently, our two propositions are disproved. The curriculum structure of the NVC learnership cannot be said to fully match the recommendations found in academic literature, and the training delivery does not unproblematically develop entrepreneurs, as required by the NSDS strategy. However, the results also suggest that the programme has many strengths, which contribute to achieving the goals of the NSDS, and that the limitations outlined above can be remedied with relative ease. Therefore, the initiative is a very positive step towards achieving the objectives of the NSDS and better understanding and facilitating the entrepreneurial development process.

9

\section{Conclusions}

This study took relevant constructs from secondary literature about the content and execution of entrepreneurial training programmes, and synthesised them into a concise assessment framework. This framework we then used to evaluate the NVC learnership as presented by the Provincial Skills Development Pilot Project of the Department of Labour and the Danish Government. Our evaluation finds that this training programme exhibits many of the necessary characteristics outlined in the evaluation framework. The major strength of the programme is its experiential approach, which requires that learners create tangible new ventures. The project impact evaluation report (Prodigy, 2005) shows that the programme has successfully prompted some business creation (i.e. tangible business activity among the 58 per cent of participants who remain in the programme). However, certain limitations were also found, which prevent the programme from satisfactorily achieving the NSDS's objectives for the development of entrepreneurs. The sustainability of the newly created ventures, which is the real measure of the programme's success, can only be measured though longitudinal study. Overall, we can say that the programme exhibits tremendous promise, but must address its limitations if it hopes to meet the ambitious targets set by the NSDS.

Importantly, the ideal learner profile for such a learnership programme is a candidate with some previous business experience, not a recently graduated high school student with very limited technical and life skills. It is possible that, in trying to achieve the target number of learners set by the NSDS, selectors for the programme circumvent the stricter requirements of the candidate screening procedure. However this is a short-term solution, since it will in the long term result in more learners dropping out of 
the programme, and so limit the success of the learnership process. Thus the NVCL programme output can be enhanced by improving the selection of learners for the programme. Administrators have to learn to correctly identify early entrepreneurial potential.

Finally, the degree of agreement between the quantitative assessment and the results from the questionnaires suggests that the assessment model developed here based on Pretorius (2001) is a successful evaluation model for entrepreneurial interventions.

\section{0}

\section{Limitations and future research}

The basic shortcoming of this study, which is shared by all attempts to assess entrepreneurial interventions, is the lack of empirical methods for evaluating the assessment framework. Consequentially, the evaluation of the programme is subjective, based on an understanding of the specific programme obtained from secondary sources. Including qualitative input from the respondents (practitioners via interview questionnaires) does mitigate this problem somewhat, and improves the validity of the findings.

Bias is also a limitation, both in the questionnaire and the secondary literature used for the evaluation. The study did not use a representative sample of respondents for the questionnaire, so some bias is possible; however this appears not to have influenced the assessment outcome as both positive and negative aspects were identified in the questionnaires. The impartiality of the authors of the secondary literature is more difficult to assess; this thus constitutes a limitation of our study.

Future research should definitely empirically investigate the impact of an individual facilitator's knowledge and experience on the overall outcomes of the programme. A longitudinal assessment of the eventual sustainability of the new ventures created through the programme is also needed.

\section{References}

1 ALBERTI, F.; SCIASCIA, S. \& POLI, A. (2004)

"Entrepreneurship education: Notes on an ongoing debate". Proceedings of the 14th Annual IntEnt Conference 4-7 July 2004, University of Napoli Federico II, Italy.

2 AMOS, T.L. \& MAAS, G. (2001) "Developing entrepreneurial students: a proposal of the what and how", Proceedings of the 11th Global IntEntConference 2-4 July 2001, Kruger National Park, South Africa. Rhodes University: Grahamstown.

3 ANTONITES A.J. \& VAN VUUREN, J.J. (2004)

"An action learning approach to entrepreneurial creativity, innovation and opportunity finding", Proceedings of the 14th Global IntEnt-Conference, 4-7 July 2004, University of Napoli Federico II, Italy.

4 BOTHA, M. (2006) "Measuring the effectiveness of women entrepreneurship programme, as a training intervention, on potential, start-up and established women entrepreneurs in South Africa", Unpublished DComm thesis. University of Pretoria: Pretoria.

5 BROCKHAUS, R.H. (1993) "Entrepreneurship education: A research agenda", In Klant, $\mathrm{H}$. \& Muller-Boling, D. (eds.) Internationalizing Entrepreneurship Education and Training, IntEnt92: Dortmund: 3-7.

6 DAVIES, T.A. (2000) "Opportunity scan to identify the viability and focus areas of possible new ventures that could be established in the micro enterprise sector in the larger Durban Metropolitan area", New Venture Creation Replication Guide (Electronic CD) Department of Labour: Pretoria.

7 DAVIES, T.A. (2002) New Venture Creation: A Unique Learnership Model for the Unemployed, Provincial Skills Development Pilot Project Phase II. New Venture Creation Replication Guide (Electronic CD) Department of Labour: Pretoria.

8 DEPARTMENT OF LABOUR, (2003)

"Background information and outline of format proposals for lead service providers." New Venture Creation Replication Guide, Provincial Skills

Development Pilot Project Phase II. (Electronic CD) Department of Labour: Pretoria.

9 DEPARTMENT OF LABOUR, (2005) National Skills Development Strategy 1 April 2005 - 31 March 2010. http://www.labour.gov.za/useful_docs/doc_ display.jsp?id=9976. (Accessed 16 May 2005.)

10 DRUCKER, P.F. (2001) Innovation and Entrepreneurship. Butterworth-Heinemann.

11 FREGETTO, E. \& FRY, F. (2002) "Identifying boundaries: delineating overlaps in teaching small 
business management and entrepreneurship courses", 2002 USASBE (United States Association for Small Business and Entrepreneurship) Annual National Conference Proceedings. Reno, Nevada, 17-20 January 2002.

12 GARAVAN, T.N. \& O'CINNEIDE, B. (1994) "Entrepreneurship education and training programs: a review and evaluation, part 1", Journal of European Industrial Training, 18(8): 3-12.

13. GARTNER, W.B. \& VESPER, K.H.

(1994) "Executive forum: Experiments in entrepreneurship education, success and failures", Journal of Business Venturing, 9(3): 179-187.

14 GIBB, A.A. (1987) "Education for enterprise: Training for small business initiation - some contrasts", Journal of Small Business and Entrepreneurship, 4(3): 42-47.

15 GORMAN, G.; HANLON, D \& KING, W. (1997) "Some research perspectives on entrepreneurship education, enterprise education and education for small business management: A ten-year literature review", International Small Business Journal, 15(3): 56-78.

16 HILLS, G.E. (1988) "Variations in university entrepreneurship education: An empirical study of an evolving field", Journal of Business Venturing, 3 : 109-122.

17 HOOD, J.N. \& YOUNG, J.E. (1993)

"Entrepreneurship's requisite areas of development: A survey of top executives in successful entrepreneurial firms", Journal of Business Venturing, 8(2): 115-135.

18 IVANCEVICH, J.M. (1991) "A traditional faculty member's perspective on entrepreneurship", Journal of Business Venturing, 6(1): 1-7.

19 JOHNSON, B. (1990) "Toward a multidimensional model of entrepreneurship: The case of achievement motivation and the entrepreneur", Entrepreneurship Theory and Practice, 14(3): 39-54.

20 JORDAAN, J.W. (2002) "A multi-dimensional conceptual framework as an aid to assist in entrepreneurship development", Proceedings of the 12th Global IntEnt-Conference, 8-10 July 2002, Johore Bahru, Malaysia.

21 KLANDT, H. (1993) "Methods of teaching: what is useful for entrepreneurship education?" Proceedings of the Conference Internationalizing Entrepreneurship Education and Training, Vienna (Austria), July 5-7, 1993.

22 LABUSCHAGNE, M.; NIEUWENHUIZEN, C. \& KROON, J. (2001) "A multidisciplinary approach to the development of training programs and qualifications for entrepreneurship", Proceedings of the 11th Global IntEnt-Conference, 2-4 July 2001, Kruger National Park, South Africa.
23 LADZANI, W.M. \& VAN VUUREN, J.J. (2002) "Entrepreneurship training for emerging entrepreneurs in South Africa", Journal of Small Business Management, 40(2): 154-161.

24 LE ROUX, F.A.S. (2004) "Entrepreneurial training and development: A holistic approach to new venture creation in the Republic of South Africa", Proceedings of the 14th Global IntEntConference, University of Napoli Federico II (Italy), 4-7 July 2004.

25 LIGTHELM, A.A. \& CANT, M.C. (2003) "Small Business Problems in South Africa: Priorities for Entrepreneurial Education." Proceedings of the 13th global IntEnt-Conference, 8th-10th September Grenoble/France.

26 MAMINZA P.M.; MARAIS H.C.; MTHETHWA B.A.; MBUYANE E.M.; NKOSI A.E. \& SHABANGU A.I. (2001) "The need for and effects of entrepreneurship and technical training in deep-rural areas", International Conference for Entrepreneurship Education and Training 2-4 July 2001, Kruger National Park, South Africa.

27 McCLELLAND, D.C. (1965a) "Achievement motivation can be developed", Harvard Business Review, 43: 6-25.

28 McCLELLAND, D.C. (1965b) "Achievement and entrepreneurship: a longitudinal study", Journal of Personality and Social Psychology, 1(4): 389-392.

29 McCLELLAND, D.C. \& WINTER, D. (1971) Motivating Economic Achievement, Free Press: New York.

30 McMULLAN, W.E. \& LONG, W.A. (1987) "Entrepreneurship education in the nineties", Journal of Business Venturing, 2(3): 261-275.

31 MIRON, D. \& McCLELLAND, D.C. (1979) "The impact of achievement motivation training on small businesses", California Management Review, 21(4): 13-28.

32 NEW VENTURE AFRICA (2005) A Model for the Business Development Phase of the New Venture Creation Learnership: Report Prepared for DANIDA and SESD by New Venture Africa, Department of Labour: Pretoria.

33 NIEUWENHUIZEN, C. \& KROON, J. (2002) "Identification of entrepreneurial success factors to determine the content of entrepreneurship subjects", South African Journal of Higher Education. 16(3).

34 NIEUWENHUIZEN, C. \& GROENWALD, D. (2004) "Entrepreneurship training and education needs as determined by the brain preference profiles of successful, established entrepreneurs", Proceedings of the 14th Global IntEnt-Conference, 4-7 July 2004, University of Napoli Federico II, Italy. 
35 ORFORD, J.; HERRINGTON, M. \& WOOD, E. (2004) Global entrepreneurship monitor 2004: South African Report. UCT Centre for Innovation and Entrepreneurship, Graduate School of Business, University of Cape Town.

36 PLASCHKA, G.R. \& WELSCH, H.P. (1990) "Emerging structures in entrepreneurship education: curricular designs and strategies", Entrepreneurship: Theory and Practice, 14(3): 55-71.

37 POOE, R, (2002) "Outcomes-based education as a vehicle to entrepreneurship education and training", Proceedings of the 12th Global IntEnt Conference, July 8-10, 2002 Johor Bahru, Malaysia.

38 PRETORIUS, M. (2000) "Evaluation of a proposed training methodology to enhance micro and small business start-ups in South Africa”, Proceedings: ICSB World Conference. Brisbane. Australia.

39 PRETORIUS, M. (2001) "A training model to enhance micro and small business start-ups in South Africa", Unpublished DTech thesis. Transvaal University of Technology: Pretoria.

40 PRETORIUS, M. \& MAARTENS, W.P. (2001) "Application of a proposed evaluation instrument to evaluate venture start-up training programmes", Proceedings of the 11th Global IntEnt-Conference, 2-4 July 2001, Kruger National Park, South Africa.

41 PRETORIUS, M.; NIEMAN, G. \& VAN VUUREN, J.J. (2005) "Critical evaluation of two models for entrepreneurial education: an improved model through integration," International Journal of Educational Management, 19(5): 413 427.

42 PRODIGY (2005) DOL/SESD NVC Programme: Impact Evaluation Report Compiled By Prodigy Business Services, November 2005. Department of Labour: Pretoria.

43 REPUBLIC OF SOUTH AFRICA (1995) "White paper on national strategy for the development and promotion of small business in South Africa", Government Gazette. 28 March, 357(16317)

44 RONSTADT, R. (1987) "The educated entrepreneurs: A new era of entrepreneurial education is beginning," American Journal of Small Business, 11(4): 37-53.

45 SHAVER, K. \& SCOTT, L. (1992) "Person, process and choice: the psychology of new venture creation", Entrepreneurship Theory and Practice, 16: 23-45.
46 SOUTH AFRICAN QUALIFICATIONS AUTHORITY (2002) National Certificate: New Venture Creation (SMME) SAQA Registered Qualification.

47 TIMMONS, J.A. (1971) "Black is beautiful: Is it bountiful?" Harvard Business Review, 49: 81-94.

48 TIMMONS, J.A. (1994) New Venture Creation: Entrepreneurship for the 21st Century. Irwin: Burr Ridge.

49 TIMMONS, J.A. \& SPINELLI, S. (2003) New Venture Creation, Entrepreneurship for the 21st Century. McGraw Hill.

50 ULRICH, T.A. \& COLE, G.S. (1987) “Toward more effective training of future entrepreneurs", Journal of Small Business Management, 25(4): 32-39.

51 VAN CLOUSE, G.H. (1990) “A controlled experiment relating entrepreneurial education to students' start-up decisions", Journal of Small Business Management, 28(2): 45-53.

52 VAN VUUREN, J.J. \& ANTONITES, A.J. (2001) "Recent developments regarding content of entrepreneurship training programmes", Proceedings of the 11th Global IntEnt-Conference, 2-4 July 2001, Kruger National Park, South Africa.

53 VAN VUUREN, J.J. \& NIEMAN, G. (1999) "Entrepreneurship education and training: a model for syllabi/curriculum development", 44th ICSB World Conference Proceedings.

54 VESPER, K.H. \& McMULLAN, W.E. (1988) "Entrepreneurship: today courses, tomorrow degrees?" Entrepreneurship Theory and Practice, 13(1): 7-13.

55 VIVIERS, S.; VAN EEDEN, S. \& VENTER, D. (2001) "Identifying small business problems in the South African context for proactive entrepreneurial education", Proceedings of the 11th Global IntEnt-Conference 2-4 July 2001, Kruger National Park, South Africa.

56 WATSON, C.H. \& BOSHOFF, A.B. (1995) "Applying the entrepreneurship life-cycle framework to the identification of topic areas for teaching", Proceedings of the Int Ent Conference, Bunbury, Australia, 25-28 July 1995.

57 WICKHAM, P.A. (2004) Strategic Entrepreneurship ( $3^{\text {rd }}$ ed.) Financial Times/Pitman Publishing: London. 